\title{
The biosurfactant viscosin transiently stimulates n-hexadecane mineralization by a bacterial consortium
}

\author{
Frederik Bak • Lise Bonnichsen • Niels O. G. Jørgensen • \\ Mette H. Nicolaisen • Ole Nybroe
}

Received: 9 July 2014 / Revised: 21 August 2014 / Accepted: 27 August 2014 / Published online: 14 September 2014

(C) The Author(s) 2014. This article is published with open access at Springerlink.com

\begin{abstract}
Pseudomonas produces powerful lipopeptide biosurfactants including viscosin, massetolide A, putisolvin, and amphisin, but their ability to stimulate alkane mineralization and their utility for bioremediation have received limited attention. The four Pseudomonas lipopeptides yielded emulsification indices on hexadecane of $20-31 \%$ at $90 \mathrm{mg} / \mathrm{l}$, which is comparable to values for the synthetic surfactant Tween 80 . Viscosin was the optimal emulsifier and significantly stimulated $\mathrm{n}$-hexadecane mineralization by diesel-degrading bacterial consortia but exclusively during the first 2 days of batch culture experiments. Growth of the consortia, as determined by $\mathrm{OD}_{600}$ measurements and quantification of the alkB marker gene for alkane degradation, was arrested after the first day of the experiment. In contrast, the control consortia continued to grow and reached higher $\mathrm{OD}_{600}$ values and higher alkB copy numbers during the next days. Due to the short-lived stimulation of n-hexadecane mineralization, the stability of viscosin was analyzed, and it was observed that added viscosin was degraded by the bacterial consortium during the first 2 days. Hence, viscosin has a potential as stimulator of alkane degradation, but its utility in bioremediation may be limited by its rapid degradation and growth-inhibiting properties.
\end{abstract}

Keywords Alkanes $\cdot$ Biodegradation · Lipopeptides · Pseudomonas

F. Bak • L. Bonnichsen • N. O. G. Jørgensen • M. H. Nicolaisen • O. Nybroe $(\square)$

Section of Genetics and Microbiology, Department of Plant and Environmental Sciences, University of Copenhagen,

Thorvaldsensvej 40, 1871 Frederiksberg, Copenhagen, Denmark e-mail: oln@plen.ku.dk

\section{Introduction}

Pollution with petroleum hydrocarbons is widespread and represents a problem for the environment as well as human health. Petrol and diesel contain a high amount of aliphatic hydrocarbons, in particular $\mathrm{C}_{14}$ to $\mathrm{C}_{20}$ alkanes (Liang et al. 2005; Stroud et al. 2007). The potential to degrade alkanes has been identified in a great variety of bacteria including Proteobacteria as well as Actinomycetales (van Beilen and Funhoff 2007). The enzyme alkane hydroxylase, AlkB, is responsible for the first step in degradation of $\mathrm{C}_{5}-\mathrm{C}_{16}$ alkanes (Ji et al. 2013), and the alkB gene has been widely used as a marker for the microbial alkane degradation potential due to its widespread occurrence among degraders (Perez-de-Mora et al. 2011; Jurelevicius et al. 2013).

Microbial degradation of alkanes is often limited by the low bioavailability of these hydrophobic pollutants. Microorganisms employ two general strategies to access hydrophobic substrates and hence circumvent the limiting bioavailability. First, they can rely on biosurfactant-mediated solubilization. Biosurfactants are amphipathic molecules with varying structures produced by a diverse group of bacteria (Van Hamme et al. 2006). They can facilitate interactions between the bacteria and alkanes by generating emulsions or by pseudosolubilization of the alkane into hydrophilic micelles (Perfumo et al. 2010; Ward 2010). Second, bacteria can access alkane drops by direct cell contact and even form biofilms on the hydrophobic substrate (Perfumo et al. 2010). Biosurfactants also play a role in the direct access strategy by increasing the cell surface hydrophobicity of the degrading organism, thereby increasing adherence to the hydrophobic substrate (Hommel 1990; Bouchez-Naitali et al. 1999; Zhang and Miller 1995; Kumar et al. 2008; Al-Tahhan et al. 2000; Perfumo et al. 2010; Ward 2010; Djeridi et al. 2013). Biosurfactants may even affect the direct access strategy in a more indirect manner, as they play several roles in biofilm 
formation, and in some cases have been shown to dissolve established biofilms (Tribelli et al. 2012; Whyte et al. 1999; Ward 2010; Rivardo et al. 2009; Kuiper et al. 2004)

Various studies have been conducted on addition of biosurfactants such as rhamnolipids (Lawniczak et al. 2013) and the Bacillus lipopeptide surfactin (Moran et al. 2000; Olivera et al. 2000; Whang et al. 2008) in bioremediation processes of petroleum hydrocarbon/alkane pollutions. Often, biodegradation is stimulated by these biosurfactants (Moran et al. 2000; Kang et al. 2010), but inhibitory effects have also been observed and may be caused by toxicity of the biosurfactant, by formation of biosurfactant micelles that offer limited access to the substrate or by destruction of degrading biofilms (Van Hamme and Ward 2001; Zeng et al. 2011; Chrzanowski et al. 2011; Kuiper et al. 2004). The use of biosurfactants in bioremediation is however still hampered by lack of detailed understanding of the impact of biosurfactants on degrader activity and performance in natural environments.

It is often highlighted that biosurfactants are biodegraded easier than chemical surfactants (Mulligan 2005), but fast biodegradation of an exogenously added biosurfactant may not only be advantageous, as fast degradation may limit its potential for usage in bioremediation. However, the stability of biosurfactants is rarely investigated in alkane biodegradation studies (Frank et al. 2010).

Most studies of biosurfactant-facilitated alkane degradation have focused on single strains or mixtures of a few strains. These studies have improved understanding of the detailed mechanisms of biosurfactant-mediated hydrocarbon uptake but even revealed that such mechanisms are often strainspecific (Thavasi 2011; Ward 2010). Thus, the effects of biosurfactants added to degrader consortia are still lacking attention to improve realism of the obtained conclusions. Bacteria in a consortium probably use different hydrocarbon accession strategies, and Owsianiak et al. (2009) suggested that addition of biosurfactants to consortia stimulates biodegradation performed by the degraders taking up solubilized hydrocarbons. On the other hand, bacteria using the direct substrate accession mode may be negatively affected by biosurfactants.

Pseudomonas produces several powerful lipopeptide biosurfactants with low critical micelle concentrations (CMCs) (Raaijmakers et al. 2010). These lipopeptides, including the compounds viscosin, massetolide A, putisolvin, and amphisin, have primarily been investigated for their antimicrobial properties and their effects on biofilm formation (Raaijmakers et al. 2010). However, the ability of Pseudomonas lipopeptides to stimulate mineralization of hydrophobic hydrocarbons and their utility for bioremediation have so far received very limited attention. The aims of the current study are (1) to provide information on the ability of Pseudomonas lipopeptides to solubilize the model alkane, n- hexadecane; (2) to determine the impact of the lipopeptide viscosin on mineralization of $\mathrm{n}$-hexadecane and growth by a bacterial consortium; and (3) to obtain information about the stability of viscosin in the presence of the n-hexadecanedegrading consortium.

\section{Materials and methods}

Isolation of a diesel-degrading bacterial consortium from soil

Diesel-degrading bacteria were isolated from soils polluted with hydrocarbons (Aabenraa, Denmark). Initially, bacteria were extracted from the soils as previous described by Johnsen and Karlson (2005) with a few adjustments. Suspensions of $0.50 \mathrm{~g}$ soil and $4.5-\mathrm{ml} 2 \mathrm{mM}$ sodium pyrophosphate solution $\left(\mathrm{Na}_{4} \mathrm{P}_{2} \mathrm{O}_{7} \cdot 10 \mathrm{H}_{2} \mathrm{O}\right)(\mathrm{pH}=8.0)$ were mixed for $30 \mathrm{~min}$ on a gyratory shaker. The suspensions were streaked on Bushnell Haas (BH) (Sigma-Aldrich) agar plates with $0.1 \%$ sterile filtered diesel (Shell) and $0.1 \%$ nystatin (ICN Biomedicals Inc.) to inhibit fungal growth. Plates were incubated for 2 weeks at room temperature. Colony material from the plates was washed off by $0.9 \% \mathrm{NaCl}$ and used as inoculum for a culture in liquid $\mathrm{BH}$ medium with $0.1 \%$ sterile filtered diesel and $0.1 \%$ nystatin. The culture was incubated for 13 days at room temperature with stirring, whereupon the culture (diesel-degrading consortium) was stored at $-70{ }^{\circ} \mathrm{C}$ as $1-\mathrm{ml}$ aliquots of a $50 \% v / v$ glycerol/bacterial suspension.

\section{Purification of lipopeptide biosurfactants}

The lipopeptides viscosin, massetolide A, putisolvin, and amphisin were purified from the producing strains Pseudomonas fluorescens SBW25 (Thomson et al. 1995), P. fluorescens SS101 (de Souza et al. 2003), Pseudomonas putida 267 (Tran et al. 2008) and Pseudomonas sp. DSS73 (Sørensen et al. 2001), respectively, essentially as described by de Souza et al. (2003). Briefly, the strains were cultivated on King's B agar plates in darkness at $28^{\circ} \mathrm{C}$ for 1 day, before being transferred to $20{ }^{\circ} \mathrm{C}$ and incubated for another 3 days. Colony material was suspended in demineralized water (MilliQ, Millipore; referred to as Milli-Q water hereafter) and homogenized by shaking. Cells and supernatant was separated two times by centrifugation at $4,700 \mathrm{rpm}$ for $20 \mathrm{~min}$ at $4{ }^{\circ} \mathrm{C}$ on a Sigma $3-18 \mathrm{~K}$ centrifuge (Sciquip). The supernatant was acidified to $\mathrm{pH} 2.0$ with $1 \mathrm{M} \mathrm{HCl}$ and left overnight on ice for a precipitate to form. The solution including precipitate was centrifuged in sterile centrifuge tubes for $27 \mathrm{~min}$ at $7,000 \mathrm{rpm}$ and $4{ }^{\circ} \mathrm{C}$ in a Sigma $3-18 \mathrm{~K}$ centrifuge. The supernatant was discarded, and the precipitate was washed four times with Milli-Q water at $\mathrm{pH}$ 2.0. The precipitate was dissolved in Milli-Q water, and $\mathrm{pH}$ was adjusted to 8.0 with $1 \mathrm{M} \mathrm{NaOH}$ to fully dissolve the precipitate. The solution was 
lyophilized, and the purity of the lipopeptide preparations was qualitatively analyzed by high-performance liquid chromatography.

\section{High-performance liquid chromatography}

High-performance liquid chromatography (HPLC) analysis was carried out using a Waters Alliance series 2695 system and a Waters model 996 photodiode array detector (www. waters.com). Chromatographic analysis of the lipopeptides followed the protocol by Nielsen and Sørensen (2003) with minor modifications. Briefly, a Hypersil BDS $\mathrm{C}_{18}$ column $(100 \times 4.6 \mathrm{~mm}$ and $3 \mu \mathrm{m}$ particle size) (www. thermoscientific.com) was used for separation of the lipopeptides. Solvents were HPLC-grade acetonitrile (solvent A) and $0.1 \% o$-phosphoric acid (solvent B), mixed in a linear gradient of 15 to $100 \%$ solvent $\mathrm{A}$ from 0 to $40 \mathrm{~min}$, and of 100 to $15 \%$ solvent $\mathrm{A}$ between 40 and $44 \mathrm{~min}$. The flow rate was $1 \mathrm{ml} / \mathrm{min}$, and the column temperature was $40{ }^{\circ} \mathrm{C}$. The injected sample volume was $10 \mu$ l. The lipopeptides were monitored at wavelengths of 190 to $250 \mathrm{~nm}$. For quantification of viscosin in cultures of the diesel degrading consortium, a wavelength of $220 \mathrm{~nm}$ was applied and viscosin concentrations were calculated using purified viscosin as a standard. Handling of chromatographic data was performed using Waters Empower 2 software.

Emulsification of n-hexadecane by lipopeptide biosurfactants

The emulsification index of viscosin, amphisin, massetolide $\mathrm{A}$, and putisolvin, as well as the synthetic surfactant Tween 80 (Applichem), was determined using the assay described by Cooper and Goldenberg (1987). The surfactants were dissolved in Milli-Q water ( $\mathrm{pH} \mathrm{7.3)} \mathrm{at} 20$ and $90 \mathrm{mg} / 1$. Solutions $(5 \mathrm{ml})$ were aliquoted into disposable pyrex tubes and overlaid with $5 \mathrm{ml} \mathrm{n}$-hexadecane (Sigma-Aldrich) before vortexing at high speed for $2 \mathrm{~min}$. Tubes were left for $24 \mathrm{~h}$ at room temperature before measuring the height of the emulsified layer and the total height of the sample. The emulsification index $\left(E_{24}\right)$ was estimated as height of the emulsified layer/total height of sample $\times 100 \%$.

$\mathrm{n}$-Hexadecane mineralization and growth of the bacterial consortium

The effect of viscosin on $n$-hexadecane mineralization by the degrading consortium isolated in this study was analyzed by a ${ }^{14} \mathrm{C}$-n-hexadecane mineralization assay. Prior to mineralization experiments, the consortium was inoculated in $\mathrm{BH}$ medium with $0.1 \%$ diesel at $28^{\circ} \mathrm{C}$ on a shaker with $150 \mathrm{rpm}$. After $24 \mathrm{~h}$, a $0.1-\mathrm{ml}$ aliquot was used to establish a culture in $\mathrm{BH}$ medium with $0.1 \%$ n-hexadecane, which was incubated under the same conditions and used as inoculum for the mineralization experiments.

The mineralization assays were carried out for 14 days in infusion flasks containing 20-ml BH medium with $100 \mathrm{ppm} \mathrm{n-}$ hexadecane (Sigma-Aldrich), $3.15 \mathrm{nCi}\left[1-{ }^{14} \mathrm{C}\right]$ hexadecane at a specific activity of $55 \mathrm{mCi} / \mathrm{mmol}$ (http://www.arc-inc.com/), and 100-ppm trace element solution (Kragelund and Nybroe 1994). Viscosin was added to a final concentration of $90 \mathrm{mg} / 1$. Flasks were inoculated with the consortium preculture to obtain a starting concentration of approximately $10^{7}$ cells/ ml. ${ }^{14} \mathrm{CO}_{2}$ was collected in glass tubes with $1-\mathrm{M} \mathrm{NaOH}$ solutions, and radioactivity was measured on a Beckman LS 1801 liquid scintillation counter (Beckman Instruments, Inc.). Data were corrected for background activity (typical value of 30 DPM). Growth was determined as optical density at $600 \mathrm{~nm}\left(\mathrm{OD}_{600}\right)$ measured by an UV-mini 1240 spectrophotometer (Shimadzu). For HPLC analysis, samples of $0.5 \mathrm{ml}$ were removed and stored at $-20{ }^{\circ} \mathrm{C}$ until analysis was carried out.

\section{DNA extraction}

Samples for DNA extraction $(1 \mathrm{ml})$ were collected from above experiments in RNase/DNase-free tubes. Cell pellets were obtained by removing $900 \mu \mathrm{l}$ of the supernatant, and the pellets were immediately flash frozen in liquid nitrogen and stored at $-70{ }^{\circ} \mathrm{C}$. Prior to extraction, $100 \mu \mathrm{l}$ of lysozyme $(1 \mathrm{mg} / \mathrm{ml}$, Sigma-Aldrich) in Tris-EDTA buffer (SigmaAldrich) were added to the pellet and left for $20 \mathrm{~min}$ at room temperature. For DNA extraction, the AllPrep DNA/RNA mini kit (Qiagen, USA) was used according to the manufacturer's protocol. The final DNA extractions were stored at $-70{ }^{\circ} \mathrm{C}$ until further processing.

\section{Quantification of the alkB genes by qPCR}

The copy numbers of alkB genes were quantified using qPCR. The qPCR was carried out using a MX3000 ${ }^{\circledR}$ qPCR system (Stratagene). The alkB genes were amplified using primers alkB-f (5'-AAYACIGCICAYGARCTIGGICAYAA-3') and alkB-r (5'-GCRTGRTGRTCIGARTGICGYTG-3') (Perezde-Mora et al. 2011). This primer set amplifies alkB genes from a range of Gram-positive as well as Gram-negative bacteria without an obvious specificity for any bacterial group, and the obtained PCR product has the length of approximately $550 \mathrm{bp}$. Amplification of the fragment was carried out in 20- $\mu \mathrm{l}$ reactions using the Brilliant Master mix SYBR ${ }^{\circledR}$ GREEN which included the following: PCR buffer, dNTPs, $5 \mathrm{mM}$ $\mathrm{MgCl}_{2}$, Sure start Taq polymerase, and SYBR Green 1 dye (Agilent Technologies, Santa Clara, CA). Further, reactions contained $0.8 \mu \mathrm{l}$ of each primer $(10 \mathrm{pmol} / \mu \mathrm{l}), 2 \mu \mathrm{l}$ bovine serum albumin (New England Biolabs), $1 \mu \mathrm{l} \mathrm{MgCl} 2$ (50 mM)

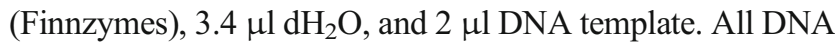


extracts were diluted tenfold before they were used in PCR reactions. The setup of the touchdown PCR program consisted of the following: initial denaturation at $95{ }^{\circ} \mathrm{C}$ for $10 \mathrm{~min}$ followed by 5 cycles of $45 \mathrm{~s}$ at $95^{\circ} \mathrm{C}, 1 \mathrm{~min}$ at $62^{\circ} \mathrm{C}$ (reduced stepwise to $57^{\circ} \mathrm{C}$ ), and $45 \mathrm{~s}$ at $72{ }^{\circ} \mathrm{C}$. This was followed of 40 cycles of $45 \mathrm{~s}$ at $72{ }^{\circ} \mathrm{C}, 45 \mathrm{~s}$ at $95^{\circ} \mathrm{C}, 1 \mathrm{~min}$ at $57^{\circ} \mathrm{C}$, and $45 \mathrm{~s}$ at $72^{\circ} \mathrm{C}$ (Perez-de-Mora et al. 2011). The PCR program was ended with $20 \mathrm{~min}$ at $72{ }^{\circ} \mathrm{C}$. The standard used was a tenfold serial dilution of alkB genes from Pseudomonas putida GPo1, and it ranged from $10^{3}$ to $10^{7}$ copies per qPCR reaction. The standard curve was linear with a $R^{2}>$ 0.99 with a reaction efficiency of the real-time PCR of approximately $75 \%$.

Data analysis

Comparison of two data sets was performed by unpaired twotailed $t$ test. Analysis of concentration correlation was done with linear regression analysis. Correlation analysis between different dependent variables was done using PAST statistics (http://folk.uio.no/ohammer/past/). All experiments were carried out with triplicate samples and with at least one independent repetition of each experiment. Data are presented as mean \pm SD. $P<0.05$ is selected as cutoff for statistical significance.

\section{Results}

Emulsification of $\mathrm{n}$-hexadecane by purified lipopeptides

Lipopeptide preparations were initially analyzed by HPLC to ensure purity of compounds used for subsequent experiments. Figure 1 shows the chromatograms obtained for the lipopeptides viscosin, massetolide A, putisolvin, and amphisin. They were all characterized by dominating peaks complemented by a few minor peaks eluding slightly earlier
Fig. 1 HPLC chromatograms obtained from preparations of viscosin, massetolide A, putisolvin, and amphisin purified from $P$. fluorescens SBW25, P. fluorescens SS101, P. putida 267 and Pseudomonas sp. DSS73, respectively. $A U$ absorbance units

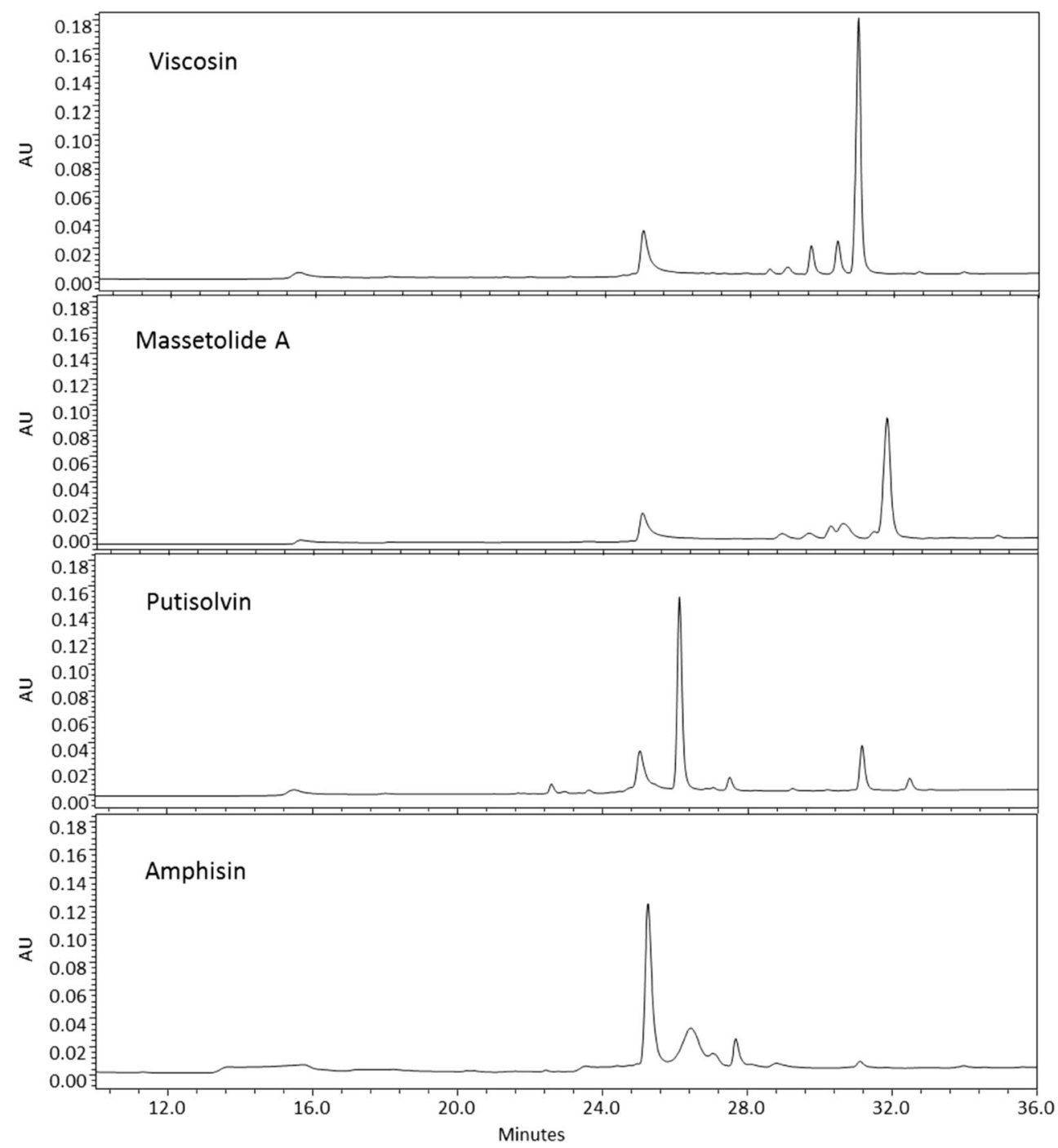


of, or later, than the major peak. The analysis documented that pure lipopeptides were obtained as the additional peaks in the chromatograms represent derivatives of the major lipopeptides generated as a result of flexibility of the synthetases involved in lipopeptide synthesis (Stachelhaus et al. 1999) as discussed below.

All the Pseudomonas lipopeptides and the commercial synthetic surfactant Tween 80 emulsified n-hexadecane with emulsification indices of 6-24\% at $20 \mathrm{mg} / 1$ and $20-31 \%$ at $90 \mathrm{mg} / \mathrm{l}$ (Fig. 2). The emulsification indexes for all compounds were dependent on the concentration, with higher values at $90 \mathrm{mg} / \mathrm{l}$ than at $20 \mathrm{mg} / \mathrm{l}(P<0.05$, except from viscosin with a $P$ value of 0.055$)$. Viscosin and amphisin had comparable emulsification powers as the synthetic surfactant Tween 80, while massetolide and putisolvin were significantly weaker emulsifiers both at 20 and $90 \mathrm{mg} / \mathrm{l}(P=$ 0.000451 and 0.0089 for massetolide; $P=0.000331$ and 0.0177 for putisolvin). Viscosin was selected for subsequent studies, as it was the biosurfactant with the highest ability to emulsify n-hexadecane.

Effect of viscosin on n-hexadecane mineralization and growth of a bacterial consortium

The effect of viscosin on $n$-hexadecane mineralization and growth of the diesel-degrading bacterial consortium was studied at a concentration of $90 \mathrm{mg} / \mathrm{l}$. The consortium treated with viscosin showed a significantly higher n-hexadecane mineralization until day 2 compared to the non-treated consortium $(P=0.027)$ (Fig. 3a). However, this stimulatory effect was only short lived, and from day 3, there was no significant difference between the viscosin-treated consortium and the control. After 14 days, the control and the viscosin-treated consortium had mineralized $37.3 \%$ $( \pm 9.4 \%)$ and $41.3 \%( \pm 9.1 \%)$ n-hexadecane, respectively.

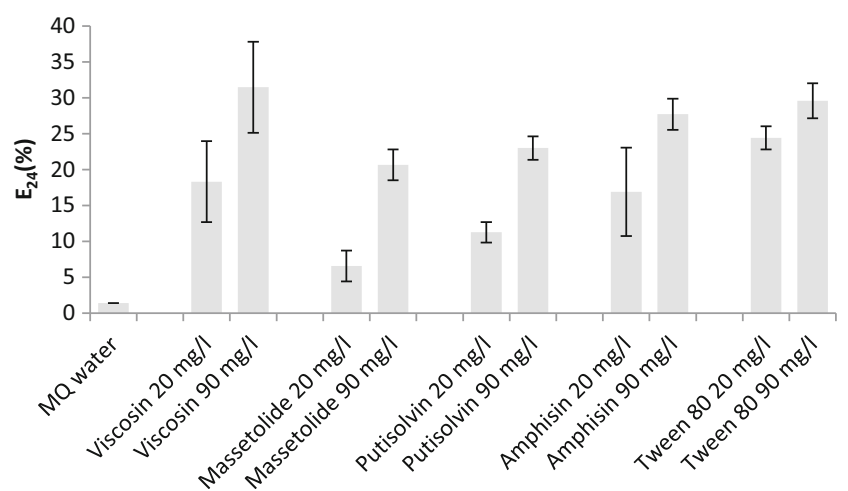

Fig. 2 Emulsification of n-hexadecane (index $\mathrm{E}_{24}(\%)$ ) obtained for Pseudomonas lipopeptides viscosin, massetolide A, putisolvin, amphisin, and Tween 80. MQ water served as control. Values are mean of triplicates with error bars representing $\pm \mathrm{SD}$
Growth of the bacterial consortium was initially assessed by $\mathrm{OD}_{600}$ measurements. Figure $3 \mathrm{~b}$ shows that the control and the viscosin-treated consortia initially grew comparably and reached an $\mathrm{OD}_{600}$ of ca. 0.3 on day 1 . Thereafter, growth of the viscosin-treated consortium was arrested while the control consortium continued to grow for three additional days and reached an $\mathrm{OD}_{600}$ of approximately 0.55 . At the end of the experiment, growth yield (final $\mathrm{OD}_{600}$ ) of the viscosin-treated consortium was significantly lower than of the control $(P<0.05)$.

To complement $\mathrm{OD}_{600}$ measurements, we quantified alkB gene copy numbers to determine the population dynamics of bacteria harboring an alkane degradation potential in the consortia. A comparable initial increase in abundance of alkB genes was observed for both consortia during the first day (Fig. 3c), while the amount of alkB genes was significantly higher in the control than in the viscosin-treated consortium after 2 days $(P=0.0028)$. In the viscosin-treated consortia, the alkB gene numbers remained constant, while those in the controls decreased after day 2 so that no significant difference was observed after 14 days $(P=0.08)$. Hence, the abundance of the alkB genes showed the same dynamics as the growth pattern observed by $\mathrm{OD}_{600}$ measurements for both the control and the viscosin-treated consortia.

To assess the ability of viscosin to stimulate n-hexadecane mineralization within the first 2 days in more detail, the mineralization per time unit normalized by the bacterial biomass expressed as $\mathrm{OD}_{600}$ is accentuated in Fig. $3 \mathrm{~d}$. The viscosin-treated consortium degraded significantly more $(P<0.05)$ n-hexadecane per biomass unit than the control in the early stage of the experiment. During the remaining time of the experiment, the treated and the non-treated consortium mineralized n-hexadecane at comparable rates.

In conclusion, viscosin has a positive effect on nhexadecane mineralization in the initial phase of the experiment while overall growth is negatively affected by the biosurfactant. Furthermore, assessment of bacterial growth by measurements of $\mathrm{OD}_{600}$ and $a l k B$ copy numbers provides comparable estimates of viscosin impact on growth dynamics.

\section{Degradation of viscosin}

The short-lived stimulation of n-hexadecane mineralization exerted by viscosin led us to investigate the stability of the biosurfactant in the experiment. Figure 4 shows the concentration of viscosin over 14 days as quantified by HPLC. The initial amount $(90 \mathrm{mg} / \mathrm{l})$ of viscosin could not be detected after the first $48 \mathrm{~h}$. At day 6 , samples were re-spiked with $60 \mathrm{mg} / 1$ of viscosin. The viscosin added on day 6 was not detected on day 7. Hence, we conclude that viscosin is rapidly degraded by members of the bacterial consortium. 
a)

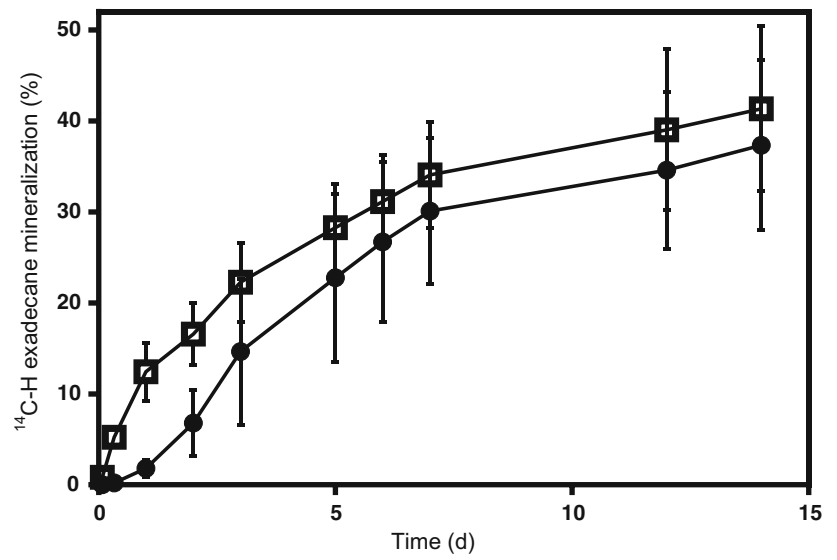

b)

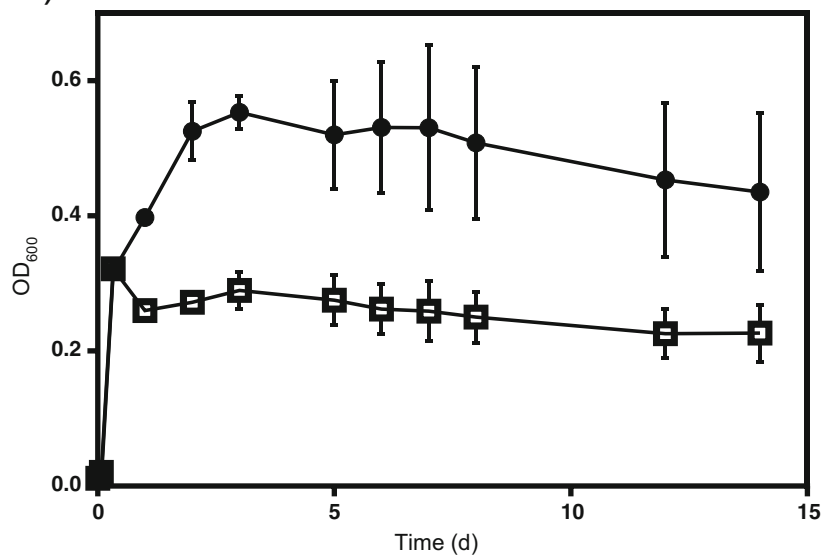

Fig. 3 The effect of viscosin on n-hexadecane mineralization and cell growth of a diesel degrading consortium. For all panels, results for consortia treated with viscosin at $90 \mathrm{mg} / \mathrm{l}$ are symbolized by squares, whereas results for control consortia are shown by circles. a Hexadecane mineralization; b growth of the bacterial consortia measured as $\mathrm{OD}_{600}$; $\mathbf{c}$

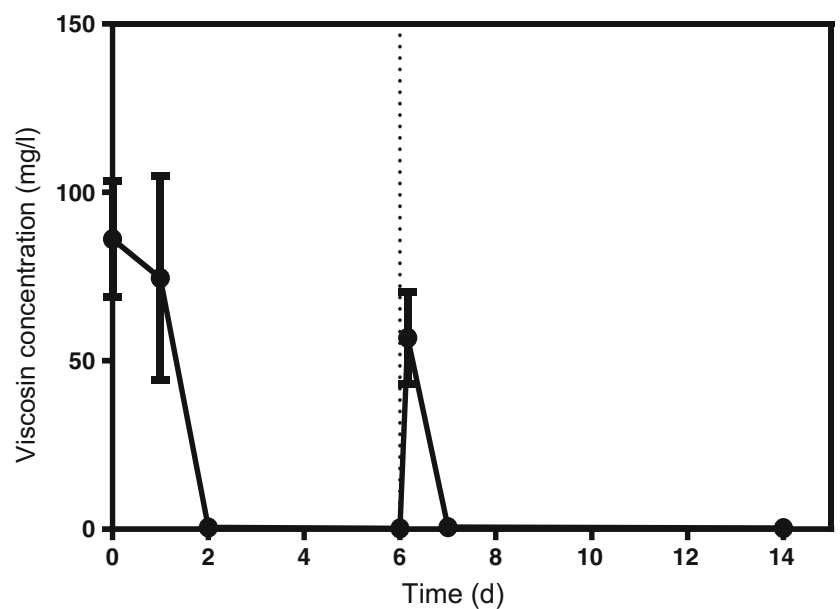

Fig. 4 The concentration of viscosin during experiments as quantified by HPLC. Dotted line represents time of spiking with $60 \mathrm{mg} / \mathrm{l}$ of viscosin. Error bars represent $1 \mathrm{SD}$ with $n=3$. Error bars not shown are smaller than the symbols c)

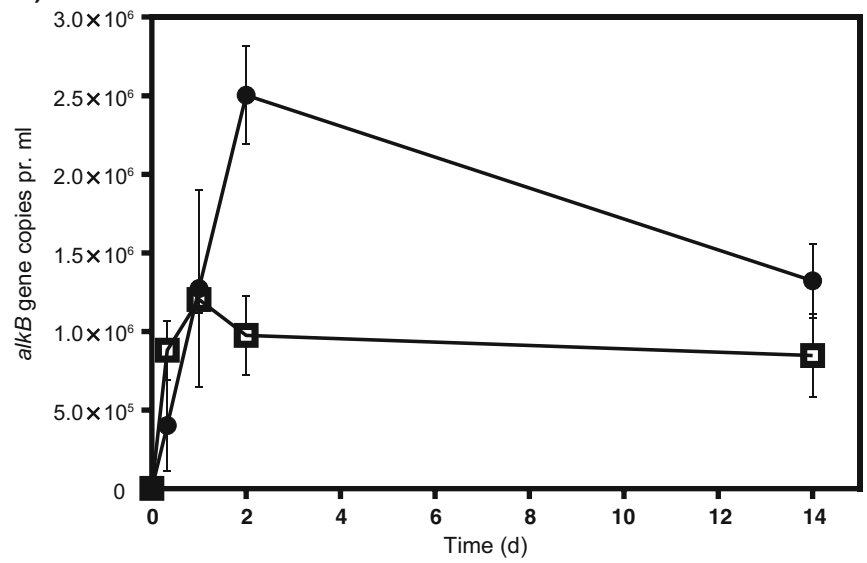

d)

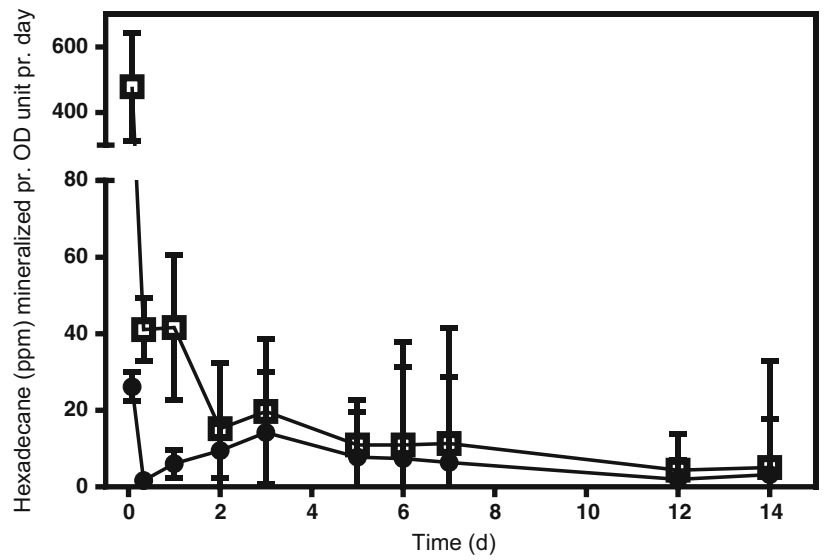

the dynamics of alkB gene copies; $\mathbf{d}$ calculated amount of n-hexadecane mineralized per day normalized by $\mathrm{OD}_{600}$ units. Note that the $y$-axis in $\mathbf{d}$ has two different intervals. Error bars represent $1 \mathrm{SD}$ with $n=3$. Error bars not shown are smaller than symbols

\section{Discussion}

Emulsification of n-hexadecane

Viscosin, massetolide A, amphisin, and putisolvin represent different groups of Pseudomonas lipopeptides. The viscosingroup compounds viscosin and massetolide A both consist of nine amino acids, while members of the amphisin group have 11 amino acids in their peptide part. Finally, putisolvin represent lipopeptides with 12 amino acids and a cyclization that differs from that of the viscosin- and amphisin-group compounds (Raaijmakers et al. 2010). All four lipopeptides are powerful biosurfactants able to lower the surface tension of water to about $30 \mathrm{mN} / \mathrm{m}$ (Saini et al. 2008; de Souza et al. 2003; Kruijt et al. 2009). These compounds are synthetized by non-ribosomal peptide synthetases, which display substrate flexibility so that an individual strain produces a major compound plus a number of structural analogues in minor amounts 
(Raaijmakers et al. 2010). This is reflected in the current chromatograms of purified viscosin, massetolide A, putisolvin, and amphisin preparations, which resemble profiles obtained by previous researchers for viscosin, massetolide A, and putisolvin. In contrast, chromatograms of amphisin have not previously been published (Kuiper et al. 2004; Tran et al. 2007; De Bruijn et al. 2007; de Bruijn and Raaijmarkers 2009; Janek et al. 2010).

We show that all the investigated Pseudomonas lipopeptides emulsify n-hexadecane in a concentrationdependent manner. Few other studies have tested the emulsification activity of lipopeptide biosurfactants at the low concentrations used in the current study. Saini et al. (2008) showed that viscosin can solubilize Pennz motor oil efficiently at $7.5 \mathrm{mg} / \mathrm{l}$, while the Bacillus lipopeptide surfactin yields an emulsification index of 10-20\% when tested at $10-20 \mathrm{mg} / \mathrm{l}$ against diesel oil (Whang et al. 2009), i.e., values comparable to those obtained here for Pseudomonas lipopeptides against n-hexadecane. Surfactin as well as pseudofactins purified from Pseudomonas have been analyzed for their emulsification properties at the much higher concentrations of $0.5 \%(w /$ v) and $1,120 \mathrm{mg} / 1$, respectively (Abdel-Mawgoud et al. 2008; Janek et al. 2010), where emulsification indices on nhexadecane of approximately $65 \%$ were reported.

Hence, the emulsification properties of the Pseudomonas lipopeptides and of surfactin seem to be overall comparable. However, our observations indicate that members of different Pseudomonas lipopeptide groups (e.g., massetolide A vs amphisin) can perform differently in n-hexadecane mineralization. Interestingly, the same holds true for structurally much related compounds within the same group of biosurfactants as massetolide A has significantly poorer emulsification properties than viscosin. These two lipopeptides only differ by a single amino acid substitution (Val vs Ile). The result underlines the importance of small structural differences for lipopeptide function, as has previously been demonstrated for their antimicrobial activities (Gerard et al. 1997). It is also worth to highlight that in studies of hexadecane emulsification properties of lipopeptides, most of them are able emulsify hexadecane to the same extent as the synthetic surfactants Tween 20, Tween 80, and Triton X-100.

\section{Effect of viscosin on n-hexadecane mineralization} and consortium growth

We investigated the impact of viscosin on n-hexadecane mineralization and on consortium growth at a concentration of $90 \mathrm{mg} / \mathrm{l}$, which is approximately 1.5 times the CMC of $54 \mathrm{mg} /$ 1 (Saini et al. 2008). This concentration was selected to enable biosurfactant-mediated substrate transfer (Bouchez-Naitali et al. 1999). Further, $90 \mathrm{mg} / \mathrm{l}$ of the related lipopeptide surfactin has previously observed in situ in a natural environment harboring introduced Bacilli (Youssef et al. 2007).
We found that viscosin stimulated $\mathrm{n}$-hexadecane mineralization during the initial $48 \mathrm{~h}$ of the experiment. Further, the biosurfactant inhibited growth, measured as turbidity as well as alkB gene copy numbers, from $24 \mathrm{~h}$ and onwards. Consequently, $\mathrm{n}$-hexadecane mineralization per time unit normalized by the bacterial biomass was dramatically increased by viscosin amendment in the initial phase of the experiment. There are a limited number of reports on the impact of lipopeptide biosurfactants on aliphatic hydrocarbon biodegradation by bacterial consortia. Hence, Moran et al. (2000) observed that surfactin added at $80 \mathrm{mg} / \mathrm{l}$, but not at $10 \mathrm{mg} / \mathrm{l}$, stimulated the biodegradation, as well as cell growth by an indigenous microbial community from ship bilge waste maintained as a liquid culture. In a comparable study, Whang et al. (2008) demonstrated that surfactin at $40 \mathrm{mg} / \mathrm{l}$ stimulated diesel biodegradation as well as biomass growth by an enriched diesel-degrading bacterial consortium in batch diesel/water cultures. However, higher concentrations of surfactin inhibited degradation of petroleum hydrocarbons in the diesel/water systems prompting the authors to conclude that the possible inhibitory effects of surfactin on bioremediation needs careful determination (Whang et al. 2008).

As addition of biosurfactants may have both stimulatory and inhibitory effects on biodegradation of hydrocarbons (Moran et al. 2000; Shin et al. 2005), it is important to have in mind that a biosurfactant affects bacteria differently, depending on their individual uptake strategies of hydrophobic compounds (Bouchez-Naitali et al. 1999). Treatment of a consortium with viscosin at concentrations above the CMC would be predicted to stimulate bacteria using biosurfactant facilitated transfer, and we speculate that $n$-hexadecane mineralization by this fraction of the consortium was stimulated in the current study, see Owsianiak et al. (2009). Viscosin, as well as surfactin, are powerful biosurfactants but concomitantly potent antibiotics (Raaijmakers et al. 2010). Neither viscosin nor surfactin have been tested systematically for their antimicrobial activity against other bacteria (Raaijmakers et al. 2010). However, it is known that viscosin is particularly active against mycobacteria with minimal inhibitory concentrations around 10-20 mg/l (Nybroe and Sørensen 2004), concentrations which the bacteria encounter in the current experiments. Mycobacterium and related bacteria with hydrophobic cell walls such as Rhodococcus are among known alkane degraders relying on the direct access strategy (BouchezNaitali et al. 1999). Hence, this bacterial group might be negatively affected by viscosin in the current experiments.

\section{Degradation of viscosin}

The short-lived stimulation of n-hexadecane mineralization by viscosin addition could be due to rapid degradation of viscosin by bacteria in the consortium. In spite of its rapid degradation, viscosin irreversibly inhibits the overall growth of the 
consortium, which could point toward an inhibitory role of a viscosin degradation product. A single report indicates that lipopeptides as arthrofactin and surfactin can be used as substrates by several bacteria in pure culture, and lipopeptide degradation is even carried out by mixed bacterial cultures introduced into soil microcosms (Lima et al. 2011). For more natural systems, the lipopeptides viscosinamide, tensin, and amphisin have been shown to reach $50 \%$ degradation with 510 days in soil (Nielsen and Sørensen 2003). Concerning degradation products, a surfactin hydrolase has recently been identified in a Streptomyces strain (Hoefler et al. 2012), but so far, lipopeptide degradation products and their specific functions have, to the best of our knowledge, not been characterized in the literature.

In conclusion, the current results show that Pseudomonas lipopeptides are efficient emulsifiers of n-hexadecane and that a selected compound-viscosin-stimulates n-hexadecane mineralization by a diesel-degrading consortium in the initial state of the degradation process. However, the toxicity and biodegradability of viscosin appears to limit its future potential in bioremediation. Previous pure-culture studies involving other biosurfactants suggest that members of the consortium with different substrate uptake strategies might respond differently to viscosin. Further investigations employing simple consortia, including strains representing the different strategies, might unravel the complex interactions between lipopeptides and different consortium members.

Acknowledgments This study was supported by the Center for Environmental and Agricultural Microbiology (CREAM) funded by the Villum Foundation. We thank Ms. Anja Sandal Grønskov for assistance during the initial work with the hexadecane-degrading bacterial consortium and Dr. Irene de Bruijn for guidance in the purification of lipopeptides.

Open Access This article is distributed under the terms of the Creative Commons Attribution License which permits any use, distribution, and reproduction in any medium, provided the original author(s) and the source are credited.

\section{References}

Abdel-Mawgoud AM, Aboulwafa MM, Hassouna NA (2008) Characterization of surfactin produced by Bacillus subtilis isolate BS5. Appl Biochem Biotechnol 150:289-303

Al-Tahhan RA, Sandrin TR, Bodour AA, Maier RM (2000) Rhamnolipid-induced removal of lipopolysaccharide from Pseudomonas aeruginosa: effect on cell surface properties and interaction with hydrophobic substrates. Appl Environ Microbiol 66:3262-3268

Bouchez-Naitali M, Rakatozafy H, Marchal R, Leveau JY, Vandecasteele JP (1999) Diversity of bacterial strains degrading hexadecane in relation to the mode of substrate uptake. J Appl Microbiol 86:421428
Chrzanowski Ł, Owsianiak M, Szulc A, Marecik R, Piotrowska-Cyplik A, Olejnik-Schmidt AK, Staniewski J, Lisiecki P, Ciesielczyk F, Jesionowski T, Heipieper HJ (2011) Interactions between rhamnolipid biosurfactants and toxic chlorinated phenols enhance biodegradation of a model hydrocarbon-rich effluent. Int Biodeterior Biodegrad 65:605-611

Cooper DG, Goldenberg BG (1987) Surface-active agents from 2 Bacillus species. Appl Environ Microbiol 53:224-229

de Bruijn I, Raaijmarkers JM (2009) Diversity and functional analysis of LuxR-type transcriptional regulators of cyclic lipopeptide biosynthesis in Pseudomonas fluorescens. Appl Environ Microbiol 75: 4753-4761

de Bruijn I, de Kock MJD, Yang M, de Waard P, van Beek TA, Raaijmarkers JM (2007) Genome-based discovery, structure prediction and functional analysis of cyclic lipopeptide antibiotics in Pseudomonas species. Mol Microbiol 63:417-428

de Souza JT, de Boer M, de Waard P, van Beek TA, Raaijmakers JM (2003) Biochemical, genetic, and zoosporicidal properties of cyclic lipopeptide surfactants produced by Pseudomonas fluorescens. Appl Environ Microbiol 69:7161-7172

Djeridi I, Militon C, GrossiV CP (2013) Evidence for surfactant production by the haloarchaeon Haloferax sp. MSNC14 in hydrocarboncontaining media. Extremophiles 17:669-675

Frank N, Lissner A, Winkelmann M, Huttl R, Mertens FO, Kaschabek SR, Schlomann M (2010) Degradation of selected (bio-)surfactants by bacterial cultures monitored by calorimetric methods. Biodegradation 21:179-191

Gerard J, Lloyd R, Barsby T, Haden P, Kelly MT, Andersen RJ (1997) Massetolides A-H, antimycobacterial cyclic depsipeptides produced by two pseudomonads isolated from marine habitats. J Nat Prod 60: 223-229

Hoefler BC, Gorzelnik KV, Yang JY, Hendricks N, Dorrestein PC, Straight PD (2012) Enzymatic resistance to the lipopeptide surfactin as identified through imaging mass spectrometry of bacterial competition. Proc Natl Acad Sci U S A 109:13082-13087

Hommel RK (1990) Formation and physiological role of biosurfactants produced by hydrocarbon-utilizing microorganisms. Biodegradation 1:107-119

Janek T, Łukaszewicz M, Rezanka T, Krasowska A (2010) Isolation and characterization of two new lipopeptide biosurfactants produced by Pseudomonas fluorescens BD5 isolated from water from the Arctic Archipelago of Svalbard. Bioresour Technol 101:6118-6123

Ji Y, Mao G, Wang Y, Bartlam M (2013) Structural insights into diversity and n-alkane biodegradation mechanisms of alkane hydroxylases. Front Microbiol 4:58

Johnsen AR, Karlson U (2005) PAH degradation capacity of soil microbial communities- Does it depend on PAH exposure? Microb Ecol 50:488-495

Jurelevicius D, Alvarez VM, Peixoto R, Rosado AS, Seldin L (2013) The use of a combination of alkB primers to better characterize the distribution of alkane-degrading bacteria. Plos One. doi:10.1371/ journal.pone. 0066565

Kang SW, Kim YB, Shin JD, Kim EK (2010) Enhanced biodegradation of hydrocarbons in soil by microbial biosurfactant, sophorolipid. Appl Biochem Biotechnol 160:780-790

Kragelund L, Nybroe O (1994) Culturability and expression of outer membrane proteins during carbon, nitrogen, or phosphorus starvation of Pseudomonas fluorescens DF57 and Pseudomonas putida DF14. Appl Environ Microbiol 60:2944-2948

Kruijt M, Tran H, Raaijmakers JM (2009) Functional, genetic and chemical characterization of biosurfactants produced by plant growthpromoting Pseudomonas putida 267. J Appl Microbiol 107:546556

Kuiper I, Lagendijk EL, Pickford R, Derrick JP, Lamers GEM, ThomasOates JE, Lugtenberg BJJ, Bloemberg GV (2004) Characterization of two Pseudomonas putida lipopeptide biosurfactants, putisolvin I 
and II, which inhibit biofilm formation and break down existing biofilms. Mol Microbiol 51:97-113

Kumar M, Leon V, Materano ADS, Ilzins OA, Luis L (2008) Biosurfactant production and hydrocarbon-degradation by halotolerant and thermotolerant Pseudomonas sp. World J Microbiol Biotechnol 24:1047-1057

Lawniczak L, Marecik R, Chrzanowski L (2013) Contributions of biosurfactants to natural or induced bioremediation. Appl Microbiol Biotechnol 97:2327-2339

Liang FY, Lu MM, Keener TC, Liu ZF, Khang SJ (2005) The organic composition of diesel particulate matter, diesel fuel and engine oil of a non-road diesel generator. J Environ Monitor 7:983-988

Lima TMS, Procopio LC, Brandao FD, Carvalho AMX, Totola MR, Borges AC (2011) Biodegradeability of bacterial surfactants. Biodegradation 22:585-592

Moran AC, Olivera N, Commendatore M, Esteves JL, Sineriz F (2000) Enhancement of hydrocarbon waste biodegradation by addition of a biosurfactant from Bacillus subtilis O9. Biodegradation 11:65-71

Mulligan CN (2005) Environmental applications for biosurfactants. Environ Pollut 133:183-198

Nielsen TH, Sørensen J (2003) Production of cyclic lipopeptides by Pseudomonas fluorescens strains in bulk soil and in the sugar beet rhizosphere. Appl Environ Microbiol 69:861-868

Nybroe O, Sørensen J (2004) Production of cyclic lipopeptides by fluorescent pseudomonads. In: Ramos JL (ed) Pseudomonas, biosynthesis of macromolecules and molecular metabolism. Kluwer/ Plenum, New York, pp 147-172

Olivera NL, Commendatore MG, Moran AC, Esteves JL (2000) Biosurfactant-enhanced degradation of residual hydrocarbons from ship bilge wastes. J Ind Microbiol Biotechnol 25:70-73

Owsianiak M, Szulc A, Chrzanowski L, Cyplik P, Bogacki M, OlejnikSchmidt AK, Heipieper HJ (2009) Biodegradation and surfactantmediated biodegradation of diesel fuel by 218 microbial consortia are not correlated to cell surface hydrophobicity. Appl Microbiol Biotechnol 84:545-553

Perez-de-Mora A, Engel M, Schloter M (2011) Abundance and diversity of n-alkane-degrading bacteria in a forest soil co-contaminated with hydrocarbons and metals: a molecular study on alkB homologous genes. Microb Ecol 62:959-972

Perfumo A, Smyth TJP, Marchant R, Banat IM (2010) Production and roles of Biosurfactants and Bioemulsifiers in accessing Hydrophobic substrates. In: Timmis KN (ed) Handbook of hydrocarbon and lipid microbiology. Springer, Berlin Heidelberg, pp $1502-1512$

Raaijmakers JM, de Bruijn I, Nybroe O, Ongena M (2010) Natural functions of lipopeptides from Bacillus and Pseudomonas: more than surfactants and antibiotics. FEMS Microbiol Rev 34:10371062

Rivardo F, Turner RJ, Allegrone G, Ceri H, Martinotti MG (2009) Antiadhesion activity of two biosurfactants produced by Bacillus spp. prevents biofilm formation of human bacterial pathogens. Appl Microbiol Biotechnol 83:541-553

Saini HS, Barraga'n-Huerta BE, Lebro'n-Paler A, Pemberton JE, Va' zquez RR, Burns AM, Marron MT, Seliga CJ, Gunatilaka AAL, Maier RM (2008) Efficient purification of the biosurfactant viscosin from Pseudomonas libanensis strain M9-3 and its physicochemical and biological properties. J Nat Prod 7:1011-1015

Shin KH, Ahn Y, Kim KW (2005) Toxic effect of biosurfactant addition on the biodegradation of phenanthrene. Environ Toxicol Chem 24: 2768-2774
Sørensen D, Nielsen TH, Christophersen C, Sørensen J, Gajhede M (2001) Cyclic lipoundecapeptide amphisin from Pseudomonas sp. strain DSS73. Acta Crystallogr C C57:1123-1124

Stachelhaus T, Mootz HD, Marahiel MA (1999) The specificityconferring code of adenylation domains in nonribosomal peptide synthetases. Chem Biol 6:493-505

Stroud JL, Paton GI, Semple KT (2007) Microbe-aliphatic hydrocarbon interactions in soil: implications for biodegradation and bioremediation. J Appl Microbiol 102:1239-1253

Thavasi R (2011) Microbial biosurfactants: from an environmental application point of view. J Bioremed Biodegrad 2:5

Thomson IP, Lilley AK, Ellis RJ, Bramwell PA, Bailey MJ (1995) Survival, colonization and dispersal of genetically modified Pseudomonas fluorescens SBW25 in the phytosphere of fieldgrown sugar beet. Biogeosciences 13:1493-1497

Tran H, Ficke A, Asiimwe T, Höfte M, Raaijmakers JM (2007) Role of cyclic lipopeptide massetolide a in biological control of Phytophthora infestans and in colonization of tomato plants by Pseudomonas fluorescens. New Phytol 175:731-742

Tran H, Kruijt M, Raaijmakers JM (2008) Diversity and activity of biosurfactant-producing Pseudomonas in the rhizosphere of black pepper in Vietnam. Appl Microbiol 104:839-851

Tribelli PM, Di Martino C, Lopez NI, Raiger Iustman LJ (2012) Biofilm lifestyle enhances diesel bioremediation and biosurfactant production in the Antarctic polyhydroxyalkanoate producer Pseudomonas extremaustralis. Biodegradation 23:645-651

van Beilen JB, Funhoff EG (2007) Alkane hydroxylases involved in microbial alkane degradation. Appl Microbiol Biotechnol 74:13-21

Van Hamme JD, Ward OP (2001) Physical and metabolic interactions of Pseudomonas sp strain JA5-B45 and Rhodococcus sp strain F9-D79 during growth on crude oil and effect of a chemical surfactant on them. Appl Environ Microbiol 67:4874-4879

Van Hamme JD, Singh A, Ward OP (2006) Physiological aspects - Part 1 in a series of papers devoted to surfactants in microbiology and biotechnology. Biotechnol Adv 24:604-620

Ward OP (2010) Microbial biosurfactants and biodegradation. In: Sen R (ed) Biosurfactants. Springer, New York. p 65-74

Whang L-M, Liu P-WG, Ma C-C, Cheng S-S (2008) Application of biosurfactants, rhamnolipid, and surfactin, for enhanced biodegradation of diesel-contaminated water and soil. J Hazard Mater 151: $155-163$

Whang L-M, Liu P-WG, Ma C-C, Cheng S-S (2009) Application of rhamnolipid and surfactin for enhanced diesel biodegradationeffects of $\mathrm{pH}$ and ammonium addition. J Hazard Mater 164:10451050

Whyte LG, Slagman SJ, Pietrantonio F, Bourbonnière L, Koval SF, Lawrence JR, Inniss WR, Greer CW (1999) Physiological adaptations involved in alkane assimilation at a low temperature by Rhodococcus sp. strain Q15. Microbiology 65:2961

Youssef N, Simpson DR, Duncan KE, McInerney MJ, Folmsbee M, Fincher T, Knapp RM (2007) In situ biosurfactant production by Bacillus strains injected into a limestone petroleum reservoir. Appl Environ Microbiol 73:1239-1247

Zeng GM, Liu ZF, Zhong H, Li JB, Yuan XZ, Fu HY, Ding Y, Wang J, Zhou MF (2011) Effect of monorhamnolipid on the degradation of n-hexadecane by Candida tropicalis and the association with cell surface properties. Appl Microbiol Biotechnol 90:1155-1161

Zhang YM, Miller RM (1995) Effect of rhamnolipid (biosurfactant) structure on solubilization and biodegradation of n-alkanes. Appl Environ Microbiol 61:2247-2251 